Teosofia: Indonesian Journal of Islamic Mysticism, Vol. 8, No. 1, 2019, pp. 13-30 e-ISSN: 2540-8186; p-ISSN: 2302-8017

DOI:

\title{
Redefining the Concept of Asceticism (Zuhd) in Tasawwuf: Abul Hasan Ash-Shadhili's View and His Tariqa Shadhiliyya
}

\author{
Erlina Anggraini \\ Northeast Normal University, China \\ erlinacendekia@gmail.com \\ Sonia So'imatus Sa'adah \\ Wuhan University, China
}

\begin{abstract}
:
Lots of the Muslims still consider that poverty is the way to get closer (taqarrub) to Allah the Most Beneficent. Such misunderstanding of Islamic teaching makes the Muslims do not have working motivation and desire. This study is a qualitative-based research. It aims to investigate and focus on Abu Hasan al-Shadhili attitude regarding wealth and his perspective about it based on his deep insight on the Qur'an and hadith. The data were gained from library research to find complete information about Syeikh al-Shadhili and his Tariqa Shadhiliyah. The analysis of the data was carried out through descriptive analysis to reveal the collected information from some documents (books, journals, and websites). One thing that makes him different from other Sufi is his concern with society, his sacrifice for people, and his country. According to him, if all salik (man undergoing spiritual journey) who are honest and pious are only busy with their religious ritual and neglect their society, dishonest and greedy people will take power and as a result, the Muslims would be neglectful of their worldly matters.
\end{abstract}

Keywords: Hadith; Qur'an; Shadhili; Wealth

\section{A. Introduction}

$\mathrm{P}$ overty is the main cause of criminal acts and suffering. But surprisingly, there are some people pleased with their poverty. It is usually caused by their misunderstanding about religion. A lot of people still misunderstood about the teaching of tasawwuf and consider that tassawuf is similar to poverty. Tasawwuf is derived from the word "shuf" which means sheep hair. ${ }^{1}$ At that time, Sufis wore coarse sheep hair as their material clothes to show their modesty, to refrain from self-

1 The other names of the Sufis in the early Islamic era are ahl Suffah means the occupant of mosque's terrace and al-Suffanah means a small branch (illustration of their thin body). 
arrogance, and to leave worldly things. Rasulullah Sallallahu 'Alaihi Wassalam said in his prayer and heard by Abu Sa'eed al-Khudri:

$$
\text { اللههم أحيني مسكينا وأميتني مسكينا واحشرني في زمرة المساكين (رو اه ابن ماجـه) }
$$

"Love the poor, for I heard the Messenger of Allah Shallahu 'Alaihi Wassalam said in his supplication: ' $O$ Allah, cause me to live poor and cause me to die poor, and gather me among the poor (on the Day of Resurrection)."

Therefore, only a few people learn deeply about tasawwuf, those who are willing to leave the pleasure of this world. Another factor is lack of religious understanding which is caused by two possibilities; the wrong working motivation that makes people become crazy of wealth or become less motivated to work and less aware that this world is full of goodness when the people can be more productive with positive activities.

Religion has an important role and influence on human life. Therefore, it is necessary to show that Islam is full of mercies and supports the Muslims looking for prosperity. Allah said:

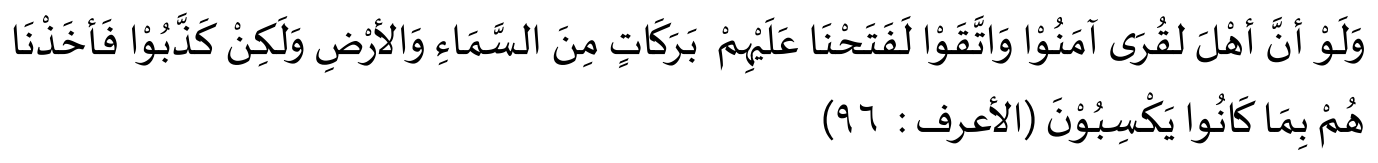

"Had the people of those towns believed and been God-fearing, We would certainly have opened up to them blessings from the heavens and the earth, but they gave the lie (to their Prophets) and so We seized them for they deeds."

Ibnu Mas'ud also said:

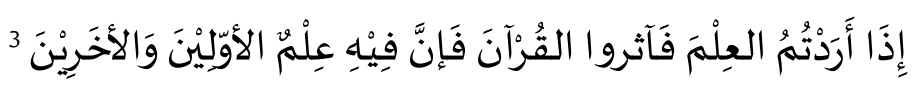

"If you want knowledge, muse the al-Qur'an because indeed in al-Qur'an there is scholars' knowledge from the beginning until the end."

Some scholars have proved it in different realms, and Imam al-Shadhili is one of them. He is a Sufi, influential Islamic scholar and a founder of the Shadhiliyah Sufi Order (Tariqa Shadhiliyah). He was born in Morocco $591 \mathrm{H}$, in a royal family of a businessman in Bani Yafrah. He was very influential and became very famous and well-known because he succeeded to implement both worldly matter and hereafter. All the above was because of his deep insight on the Qur'an and Hadith.

Moreover, Tariqa Shadhiliyyah is one of the most famous tariqa in the world of Sufism. The founder of this tariqa, Syeikh al-Shadhili, taught his disciples to be rich

2 Sunan Ibn Majah in chapter Majalisatu al-Fuqara section 2

3 Jamaluddin bin Muhammad al-Qosim, Mau'izhatu al-Mu'minin, (Dar al-Ulum al-Islamiyyah), p. 72 
and avoid jobless but let there be no in their hearts (the wealth should be in their hands not in their hearts). Syeikh Shadhili was also a rich man at that time, but his heart was always tawadhu (humble and aware of one's nothingness before Allah). That is the reason why many people are interested in this Sufi order. Except based on Qur'an and Hadith, this Tariqa also seems very moderate and wise towards good and chattel without disregard the afterlife.

Taking good actions or examples from the scholars who have an excellent understanding of the Qur'an is the best way to conceive the wealth advantages in the Qur'an to make people more aware of the benefit of having money to earn the happiness both in the world and afterlife. This study aims to view Syeikh AsyShadhili's perspective about wealth based on his thorough insight of the Quran and Hadith and what the moral value or wise value from Syeikh as-Shadhili to support the national economy?

The results of this study will help people to increase productivity so that people can responsibly utilize and maximize national economic potential. Besides, the results also will give more knowledge about tasawwuf which will bring up the economic activists holding the morality of religious values. That was the importance of religious morality which is to give humanity values based on al-Qur'an and Hadith.

\section{B. The Origin of Tasawwuf}

Both in the Qur'an and the reality when Rasulullah was still alive, there was no clear definition about tasawwuf, but the essence of tasawwuf and the teaching has been emerged and implemented. The word "tasawwuf" has emerged in the middle century of 3 Hijriyyah by Abu Hasyim al-Kufy, and he put the word "al-Sufi" as his last name. ${ }^{4}$

Etymologically, the word tasawwuf was derived from the Arabic language but there are different opinions about the root of that word as follows:

1. Ahl al-shuffah, the epithet of some poor Muslim groups in the Prophet's and khulafa al rasyidin's era.

2. Al-Shafa, means pure because the Sufis were deemed to be people who were clear of misbehavior or vicious action and secular desire.

3. Al-Shaf, means row or line because the Sufis always in the first line or first row in praying Jama'ah (together). Besides, the Sufis will be in the first line in the presence of Allah.

4. Al-Shufanah, is a sort of tall and thin plant. The reason is that its physical is like a Sufis.

4 M. Amin Syukur, Menggugat Tasawwuf: Sufi dan Tanggung Jawab Sosial Abad 21, (Yogyakarta: Pustaka Pelajar, 1999), p. 7 
5. Al-Shuf, means fleece because at the beginning the Sufis were wearing fleece clothes as their symbol of simplicity.

6. Theosophy, literally "God-wisdom" or "Divine-wisdom", these words come from Greek (Theos means God, sophia means wisdom) . $^{5}$

While terminologically, some scholars have made various definition of tasawwuf. ${ }^{6}$ Al-Junaid al-Bagdadi (d. $289 \mathrm{H}$ ), a modern Sufi figure said that tasawwuf is the way to purify the heart from malign intention and misbehavior, controlling the ego and human bad attitude, practicing spirituality, adhering to the true knowledge, advising and guiding people, keeping promises to Allah $T a$ 'ala, and following the paths of Rasulullah Sallallahu 'Alaihi Wassalam. Abu Qasim Abdul Kari Al-Qusyairi, gave a definition that tasawwuf lays out the teaching of al-Qur'an and as-Sunnah, fight to control the lust, shun the bid'ah attitude (harmful religious innovation) nor make a joke towards religious acts. And Abu Yazid al-Bustami said that tasawwuf has 3 aspects, such as kha (release from contemptible), ha (do every good deed), and jim (being close to God).

Some other definitions for the rest of many Islamic scholars agree that tasawwuf means quit doing contemptible and fight to always do better deeds through the process called riyadhah (practice) and mujahadah (do utmost). The word tasawwuf is unclearly mentioned in Qur'an, but some verses show and strengthen that tasawwuf teaching is from the Qur'an, such as:

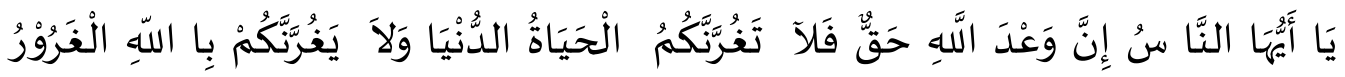

$$
\begin{aligned}
& \text { (الفَاطِرُ : (0) }
\end{aligned}
$$

"O mankind, indeed the promise of Allah is truth, so let not the worldly life delude you and be not deceived about Allah by the Deceiver. (al-Fatir: 5)"

Besides, in the Qur'an Surah Ali-Imron: 3 suggested people to be more patient to get closer to Allah, Allah gives command to worship Him only for getting His blessings (al-Bayyinah: 5), being honest (al-Anfal: 58), qana'ah, humble and not arrogant (al-Isra': 37), fair and piety (al-Maidah: 6), confident and surrender (al-Anfal: 49), worship Him with full of expectancy to get His blessings (raja) (al-Kahf: 110), fear of His anger (khauf) (at-Tahrim: 6) ${ }^{7}$.

\section{Various View about Wealth Ownership in the Practices of Sufism}

Saliks (the followers of Sufi) have different thoughts about wealth that can

\footnotetext{
5 Muhtarom, Pendidikan Tasawwuf, (Semarang: Rasail Media Group, 2010), p. 1-2

6 Tamami HAG, Psikologi Tasawwuf, (Bandung: Pustaka Setia, 2011), p. 27

HAG, Psikologi Tasawwuf, p. 29
} 
influence their attitude towards their life. The differences emerged because of different arguments or opinions towards Qur'an, hadith, Prophet's history, and his companions.

The classical Islamic scholars argued that wealth can be an obstruction (hijab) between people and God. They were extremely cautious to keep their relationship with God, and always tried to never ever forget Him because of others. That the reason they shunned this worldly life. One of the famous Sufis in the classical era was Hasan alBasri $^{8}$, his teaching about khauf was very well-known even today. Indeed, people ever said that the hellfire just created for him because he was very extremely cautious with everything about this world's pleasure, even for halal things. It was strengthened by his statement "I love to eat once and can survive forever, just like cement mix with water that could be strong forever"?

While contemporary scholars are not too strict as previous scholars. For instance, Mohammad Iqbal well said that the world is something good and right (haq). HAMKA (Indonesian Muslim scholar) also had a positive perspective and argument about the world, he suggested to use the wealth in a positive way and be cautious because it can cause misfort une when it misused.

In addition, HAMKA also argued that people should balance between body and soul. He said that wealth can keep people's honor, they can worship and do some good deeds with their money, neither sponged off people nor have debts. ${ }^{10}$

\section{Sufi Orders (Tariqa)}

The term of Sufi orders (tariqa) in Sufi world is very common. It was derived from the Arabic language "Thoriiqun" which means the path or method, precisely the path to God. According to Al-Jurjani 'Ali bin Muhammad bin 'Ali, Sufi orders (tariqa) is a particular method for Salik (the follower of Sufi) to get the closeness relationship with Allah by some steps (maqamat). ${ }^{11}$

In Sufi orders there are some components including spiritual master (murshid), disciple, bai'at (pledging spiritual allegiance/totally surrender to a spiritual master to guide disciple to Allah Ta'ala), teaching and silsila (chain, link, or connection from spiritual master to his spiritual descendant). Some of Sufi orders argued that the true Sufi orders are those that have complete components, particularly silsila, because when

\footnotetext{
8 One of the influential Sufis in companion's era, born in Madina $21 \mathrm{H} . / 641 \mathrm{M}$.

9 M. Amin Syukur, Zuhud di Abad Modern, (Yogyakarta: Pustaka Pelajar, 2004), p. 66

10 Syukur, Zuhud di Abad......, p. 131-132

11 Fazlur Rahman, Islam, (Chicago: University of Chicago Press, 1979), p. 156-157
} 
the silsila disconnect with the Holy Prophet and no ijaza (license to teach Sufi) from the spiritual master so the Sufi order (tariqa) is not valid/illegal (ghairu mu'tabarah). ${ }^{12}$

Sufi order grouping is unclearly mentioned between mu'tabarah (legal) and ghairu mu'tabarah (illegal). People often argued that the groups which do not have complete components, particularly do not have obvious silsila, are ghairu mu'tabarah (illegal) and vice versa.

While, Zamakhsari Dhofier said in his book "Tradisi pesantren: studi tentang pandangan hidup Kyai" (The tradition of Islamic boarding school: The study of life perspective of spiritual master), as cited M. Zainuddin Daulay in his Thesis titled "Tarekat Mufaridiyah: Suatu kajian tentang gerakan sosial keagamaan di Tanjungpura, Sumatera Utara pada masa orde baru" (Mufaridiyah Sufi Order (tariqa): The study of social-religious movement in Tanjungpura, North Sumatra in new order government), said that the assessment of legality of Sufi order must have some criteria, such as:

1. Practicing the shari'a Islam

2. Keeping faith with Islam and follow one of 4 madhabs (sects)

3. Practicing worship and mu'amalat (Islamic jurisprudence or fiqh) as ulama' shalihin did and taught.

While if there are local Sufi orders (tariqa) that have good lessons and not deviate from Islamic teaching (Qur'an and sunnah), so people are not able to claim that those orders are illegal (ghairu mu'tabarah), even if the silsila (chain) disconnect to the Prophet because the aim is The One (God).

While the illegal group (ghairu mu'tabarah) is the group having an unclear sanad (a chain of authenticated narrators) and the teaching deviates from Shari'a Islam, Qur'an, and Sunnah.

\section{E. A Short Biography of Abul Hasan al-Shadhili and His Intellectual Journey}

His name is Ali ibn Abdillah ibn Abdul Jabar ibn Abi Thalib. He was born in Morocco, Ghamarah village $593 \mathrm{H}$. He was brought up by his parents, became a smart boy and have a well-behaved. His parents also guided him to memorize Qur'an since he was a child, practiced sunnah, and other religion lessons. As time goes by, when he reached 6 of his age he decided to go to Tunis for the sake of knowledge. Even his parents had sufficient wealth, well-educated and pious among people, but he felt that he should go to another country and met some scholars to get more deep knowledge.

When he arrived at Tunis, he saw the people were not in good condition. The danger of famine happened at that time, he was sad and he said to himself that, "If I had the amount of money, I would buy a lot of food for them."13

12 M. Amin Syukur, Tasawwuf Kontekstual, (Pustaka Pelajar: Yogyakarta, 200), p. 45-46 
Indeed, those lovers of God are the scholars. As Allah said in Qur' an surah alFatir 28:

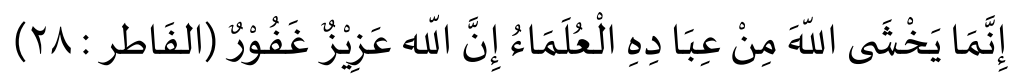

"...only those fear Allah, from among His servants, who have knowledge. Indeed, Allah is Exalted in Might and Forgiving."

Likewise, Ali, his love for the knowledge brought him to find the Exalted of God. He was not only mastering the knowledge of syari'ah zhahiriyah, but also literature, language, and other lessons, particularly the knowledge of the truth. ${ }^{14}$

His intellectual journey started from age 6, under the guidance of Syekh Abi Sa'id for about 19 years to learned about religion lessons such as Qur'an, hadith, fiqh, tawhid, and others. He also went on pilgrimage to Mecca with Syekh Abi Sa'id and had chances to study with other Islamic scholars from around the world in Mecca.

But 19 years was not make him satisfied, he realized that his knowledge was not deep. Whereupon he stayed in Mecca, he decided to go to Iraq to meet the spiritual master in that country. Unfortunately, when he reached Iraq he could not find the master and no one knows about him. Afterward, he met Sheikh al-Shalih Abu al-Fatah al-Wasithi and he said :

"O young, indeed the master you are looking for are in your country. Now he is in a great Quth al-Zaman, that is your country. So, go back to Morocco sooner than you have to spend your time looking for him here, you will not find him. Now, he is in his contemplation place, in a cave on the mountain. Go and meet him."

Then Ali went back to Morocco. After he spent a long time walking to find the master he was looking for, finally, he met the hunted spiritual master on the peak of the mountain. He is Syeikh Abu al-Fatah or Sayid Syeikh al-Shalih al-Quthub al-Gauts al-Syarif Abu Muhammad Abdul al-Salam bin Masyisyi al-Hasani (d. 625 H/1228 M). Without any acquaintance, Syeikh Abu al-Fatah said to Ali, "O Ali, you come to me as a faqir (poor people), both your knowledge and your good deeds, so you will take from me the wealth from the two worlds (this world and afterlife)". Syeikh Abu al-Fatah had already known who is Ali before he came because the Prophet told him and said that Ali should learn firsthand from him. ${ }^{15}$

\footnotetext{
13 Miftahusurur Anwar \& Mudhor Ahmad Assegaf, Imam Ali Abil Hasan As-Shadhili: Kepribadian dan Pemikiranya, (Brebes: Al-Anwar, 2002) p. 8

14 Miftahussurur Anwar \& Mundhor Ahmad Assegaf, Sabilus Salikin: Jalan Para Salik, Ensiklopedi Thariqah/Tasawwuf, (Pasuruan: Pondok Pesantren Ngalah, 2012), p. 438-441

15 Ibid., p. 438-441
}

Teosofia: Indonesian Journal of Islamic Mysticism, Vol. 8, No. 1, 2019 
After several years, Syeikh Abu al-Fatah asked Ali to practice his knowledge. He said, "O my son Ali, you have already learned many things from me, now it is your turn to practice what you have gotten..." Syeikh Abu al-Fatah asked him to go to a district named Shadhiliah. Since that time, Ali ibn Abdillah ibn Abdul Jabar ibn Abi Thalib was very well-known as Syeikh Shadhili, it was derived from the name of that district.

After arrived in Shadhiliah, Syeikh Shadhili could not stay around the people. It was unsurprisingly because Syeikh Shadhili spent his whole life looking for knowledge and busy to worship. Then, he decided to isolate and contemplate in Zaghwan mountain for several years. After that, Allah commanded him to come back to the people in the hillside, "At that time, Allah commands me, "O Ali, come back to your people, so they would be able to get benefit from you". ${ }^{16}$ Afterward, no doubt for him to be with his people and share everything he had.

\section{F. Tariqa Shadhiliyya}

Tariqa Shadhiliyah (Shadhiliyah Sufi Order) is one of the popular Sufi orders in the Sufi world. Abû al-Hasan al-Syâdzili 'Alî bin 'Abdillah bin 'Abd al-Jabbâr alSyâdzili from Ghumarah Morocco was the founder of this Sufi Order. He is the twenty-second generations of the Holy Prophet as follow: The Prophet Muhammad, Sayyidina'Alî bin Abî Thâlib dan Fâthimah al-Zahra', Sayyidinâ Hasan, Hasan alMuthannâ, 'Abdullâh, Idrîs, Umar, Idrîs, 'Isa, Muhammad, Ahmad, 'Alî, Bathâl, Wardi, Yusya', Yûsuf, Qushayy, Khâtim, Hurmuz, Tamîm, 'Abd al-Jabbâr, 'Abdullâh. ${ }^{17}$

Tariqa Shadhiliyah was rapidly developed in Tunisia, Egypt, Aljazair, Sudan, Suriah, Arabia peninsula, and Indonesia (particularly in East Java and Central Java). Live as an ascetic and jobless are strictly prohibited by Syeikh Shadhili. He argued that the proper basic necessities such as food, clothing and vehicle could causes sense of gratitude and vice versa. People should thankful for mercies and utilize everything in a good way as Allah commanded. ${ }^{18}$

This tariqa also has some hizb which are very famous, such as Hizb al-Bahr, Hizb Nashr, and Hizb Ali Habi al-Hasan al-Shadhili.

The word tasawwuf for some people reminds them of poverty, dirtiness, being busy with worship and relying on their daily needs with other people. No wonder,

16 Ibid., p. 442

$17 \quad$ Ibid., p. 437

18 Prof. Dr. H. Amin Syukur, M.A. in his lecture Tariqa and Suluk with the topic "Tarekat Shadhiliyah" on September 30, 2013 
because the word of tasawwuf itself describes the conditions of ahl suffah during the time of Prophet Muhammad.

However, the life of a Sufi figure -Shadhili-was extremely different from that ahl suffah. This contradiction drives the authors to question which salik is the right or better. The Prophet himself said that "the giving hand is better than the receiving hand ${ }^{19}$ ". But why does the prophet really love ahl suffah who lived at the terrace of the mosque and even could not fulfill their own need?

Shadhili is a highly educated person. It is clear, knowledge can lead a Muslim to devotion (taqwa). Sheikh Ibrahim bin Ismail said in Ta'lim Muta'lim:

$$
\text { ولا يصح الزهد والتقوى مع الجهل }
$$

"Zuhud and taqwa are wrong without knowledge"20.

In this case, it is important to know the context of the history, particularly the history of Islamic civilization. When the Prophet and his companions migrated to Medina, the first thing they do was to build the Nabawi Mosque. They were facing an economic issue because Muhajirin - the people who came to Medina-came without taking their wealth with them. The solution for this issue was brotherhood, the Prophet makes Muhajirin and Anshor like brothers and sisters, the people who welcomed and helped them. Some of Muhajirin were living at the mosque terrace, they did not have an income because Makkah people boycotted the trade and threat them with military attack. Thus, a job was hard to find and the prophet, as well as Anshar, helped them based on the spirit of brotherhood. However, they did not depend their lives on the other people ${ }^{21}$. For this reason the Prophet really loves them. Moreover, Ahl Suffah spent most of their time to listen to the prophet's teachings, read Quran and always be ready for religious struggle 22

19 Narrated by Haitsam bin Hizam, Rasulullah says:

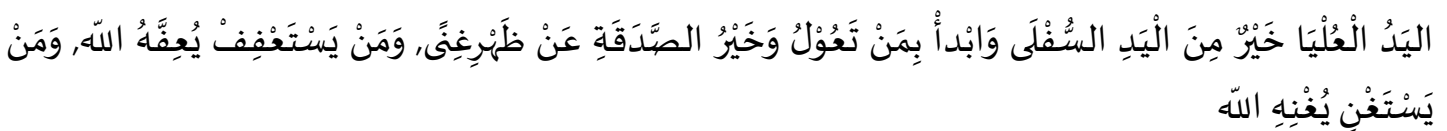

The giving hand is better than the receiving hand; Start from those who have a lot of burdens; and the best charity is charity given after one's own need. Whosoever keeps his own dignity, Allah will keep him and whosoever is feeling enough Allah will give his need (HR. Bukhori)

20 Ibrahim bin Ismail, Ta'lim al-Muta'allim, Kota Wali, p. 10

21 Muhammad Syukri Salleh, "Rethinking Wealth Management: An Islamic Preliminary View" International Journal of Business and Social Science (2102), vol. 3, p. 13

22 http://islamicencyclopedia.org/public/index/topicDetail/id/88, accessed on 2 October 2014, 21.15 WIB. 
Besides, there was one of them being marginalized by the people. Not only because of his appearance but also his family descent ${ }^{23}$. This man is Julaibib. ${ }^{24}$ Eventually, the prophet loved him because of his goodness changed the way people viewed him and made them respected him. ${ }^{25}$

Thus, by knowing the social condition of the society at that time, the authors conclude that they, ahl suffah, did not depend their lives on others because they just wanted to focus on worshiping God. It was the economic condition that forced them. However, they did not rely on other help and kept their self-esteem ${ }^{26}$.

Neither, they exiled themselves from the people which was proved by their involvement in government. Abu Hurairah was the governor in Bahrain in Umar bin Khatab era, as well as Ibn al Qurt was a governor in his era, and Ibn Mas'ud was requested to teach al-Qur'an in Kuffah by Umar bin Khatab. Even a billionaire Abdurrahman bin Auf was supporting Islam with his wealth ${ }^{27}$.

It is obvious that his attitude towards the world as well as his role in society, guiding the people and advising the politicians, does not contradict his closeness to his God. In fact, it is his way to be close to God by involving social issues and giving a positive influence in society.

23 Family lineage is extremely important for the Arabian.

24 http://www.encyclo.co.uk/define/Julaybib, accessed on 22 October 2014, 21.45 WIB

25 The prophet was the first one asking Julaibib existence after the war. See Shahih Muslim Volume 4 "Min fadhaili Julaibin ra."

26 QS al-Baqarah: 273 reveals their state.

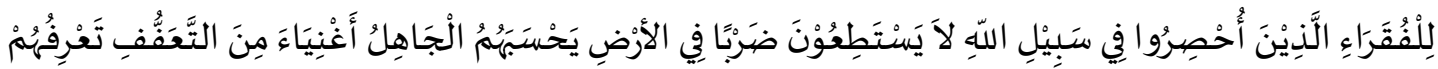

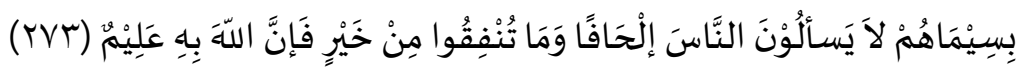

[Charity is] for the poor who have been restricted for the cause of Allah, unable to move about in the land. An ignorant [person] would think them self-sufficient because of their restraint, but you will know them by their [characteristic] sign. They do not ask people persistently [or at all]. And whatever you spend of good - indeed, Allah is Knowing of it. (http://www.alquranenglish.com/quran-surah-al-baqarah-273-qs-2-273-in-arabic-and-englishtranslation).

They were facing a critical economic issue, yet they kept their dignity and self-respect. If they were finally needed to ask for one's help, they used a polite and indirect language, and therefore only responsive and smart people could understand their purpose. M Quraish Shihab in his Tafsir alMishbah.

27 Syekh Jamaluddin in Mau'izhatul Mu'minin says:

...ترك الكسب أفضل لعالم مشغلة بتربية العلم الظاهر مما ينتفع الناس في دينهم كا لمفتى - أى الفقيه والمفسر والمحدث وامثالهم - أو رجل مشغل بمصالح الناس ... 
Based on that explanation, the authors conclude that Shadhili is a moderate Sufi figure. He is not only busy with uzlah (seclusion) and remembering God, but also advising the rulers, guiding the people, and working. He is even a rich farmer. He says:

"Whosoever preaches people to Allah by what was not preached by Rasulullah, he is a bid'iy (a person who loves to do bid'ah)'28.

For this reason, his way of life was based on his love to follow the Prophet's path, based on al-Qur' an and Hadith.

\section{G. The World is a Mosque}

Imam Shadhili eats delicious food, wears a tidy and a beautiful dress, and likes a sturdy and strong horse. If he was living in this era, he might love sport cars and any other sophisticated technologies.

He likes to wear beautiful clothes because to him the world is a mosque ${ }^{29}$. As Allah SWT says:

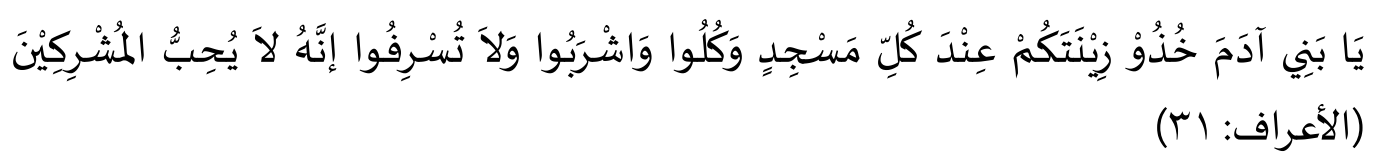

"O children of Adam, take your adornment in every masjid, eat and drink, but be not excessive. Indeed, He likes not those who commit excess" (QS Al- 'Araf: $31)^{30}$

From Jabir bin Abdillah, Rasulullah said ${ }^{31}$ :

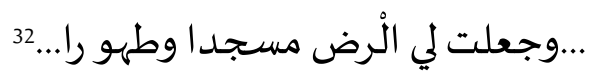

“...Allah makes this world a mosque and a pure place for me...."

The word mosque (masjid) literally comes from the word sajada-yasjudu which means to devout, submit, and be obedient. Mosque -as it is known - is a worshiping place for Muslims. However, according to its root word, the masjid is a place to do any activity devoted to Allah only ${ }^{33}$. For Shadhili, any activity he is doing, any place he is

28 Anwar \& Assegaf, Imam Ali Abil Hasan As-Shadhili:...., p. 5

29 Sri Mulyati edt., Mengenal dan Memahami Tarekat-Tarekat Muktabarah di Indonesia, (Jakarta: Kencana, 2005), p. 73-74

30 https:/www.alquranenglish.com/quran-surah-al-araf-31-qs-7-31-in-arabic-and-english-translation, accessed 15 September 2018, 2.59 pm.

31 This hadith explains the special mercy given to the prophet, which is not be given to other prophets.

32 Ibn Hajar al Asqalani, Fathul Bari Syarah Shahih al Bukhari: Volume 3. Translated by Amirudin, (Jakarta: Pustaka Azzam, 2002), p. 17

33 Muhammad Quraish Shihab, Wawasan al- Qur'an, (Bandung: Mizan, 1996), p. 452-453. 
going to is dedicated to his God. Thus, he always wants to give his best either in his effort or his appearance because anywhere he goes, God is always with him.

\section{H. The World Beauty is more than God's Mercy}

Shadhili did not encourage his disciples to leave the material world because Allah has bestowed it for humans, He says:

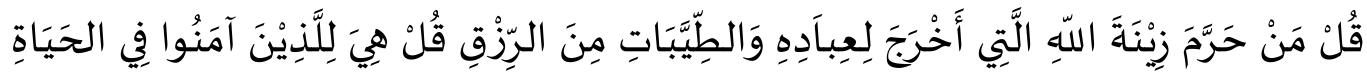

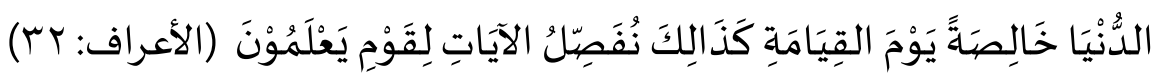

"Who has forbidden the adornment of Allah which He has produced for His servants and the good [lawful] things of provision?" Say, "They are for those who believe during the worldly life [but] exclusively for them on the Day of Resurrection." Thus do We detail the verses for a people who know". (QS Al'Araf: 32)

Allah Himself makes the desire (syahwah) beautiful for humans. Syahwah is the heart tendency toward worldly things and material things which is difficult to ignore ${ }^{34}$. One of the lessons of the function of syahwah is explained by Rasyhid Ridho in his tafsir al-Manar:

$$
\begin{aligned}
& \text { ولقد كانت غزيزة حب الزيناة وغيزة حب الطيبات من الرزق سببا لتوسع البشر فى الفلاح }
\end{aligned}
$$

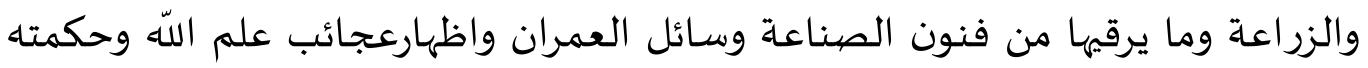

$$
\begin{aligned}
& \text { وقدرتاه في العلم, ورحمتاه واحسانه بالخلق... }
\end{aligned}
$$

'Indeed, humans' nature to love adornments and good things (thayyibat) is a blessing in order to develop agriculture, farming, and improve other things either for industrial needs or for developing in general. It also shows the magnificence of His wisdom and knowledge, His power in science, His love, and His goodness to His creatures."

Further, Rasyid Ridho states that there would be no advance and civilization if humans lived just to fulfill their own need only to survive, which would be similar to animals $^{35}$. Thus, our desires for adornments can lead us to God the All-Mighty. For this reason, the believers are encouraged to look for more than what they need to survive, al-Qur'an names it as fadhl, the surplus from Allah ${ }^{36}$. One of the reasons for

\footnotetext{
34 Muhammad Quraish Shihab, Al-Misbah, vol., 4, (Jakarta: Lentera Hati, 2012), p. 32

35 Rasyid Ridha, Tafsir al-Manar, (Beirut: Dar al-Kotob al-Ilmiyah, 2005), p. 433

36 QS. Al-Jumu'ah: 10
} 
this encouragement is in order to support Islam with their wealth by almsgiving and other goodness. Narrated by Ibnu Umar, the prophet says ${ }^{37}$ :

$$
\text { تبني الإسلام على خمس شهاة أن لاإله إلاالله وأن محمد رسولا اللّه وإقام الصلاة وإيتاء الزكا }
$$

"Islam is established by five pillars; bear witness that no God except Allah and indeed Muhammad is His messenger, pray, give almsgiving, and fast during Ramadhan."

One of the names al-Qur' an uses to call wealth is khair $^{38}$ which means good. It reveals that not only the way to get the wealth is lawful and good, but also it should improve the believers' lives as a human as well as His servant ${ }^{39}$. Therefore, Shadhili always prays:

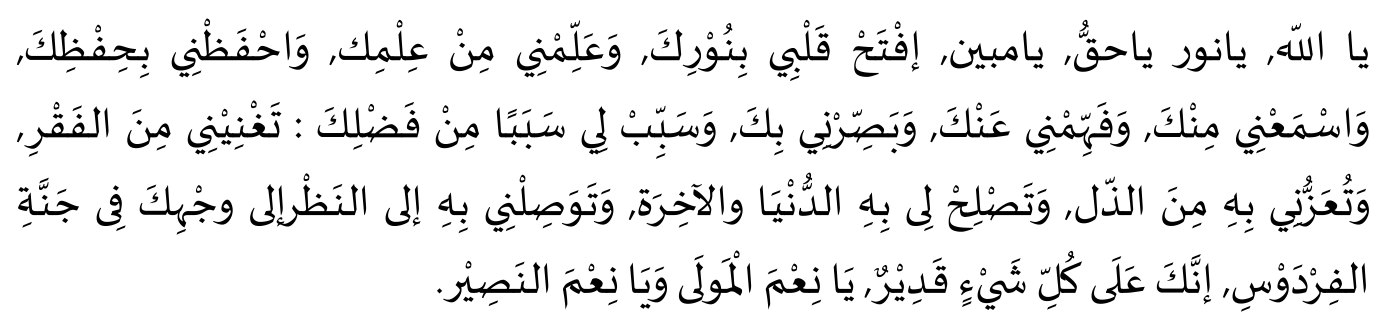

"O Allah, $O$ the Light, $O$ the Truth, $O$ the Real, please open up my heart with Your light, teach me with Your knowledge, protect me with Your affection, make me listen to what is coming from You, bestow me with the fathom about You, give me the sight with You, give me Your mercy which enriches me from poorness, honors me from deprivation, beautify my world and hereafter, allow me to see You in Firdaus paradise. Indeed You are the All Capable for everything, $O$ the best Protector, $O$ the best Rescuer ${ }^{4 O}$."

\section{The World is Hereafter Investment}

A rich and hard worker man, Shadhili, had a wide field. Even he planted and harvested his farming as well. A lot of people were insulting him saying that he did not deserve to be a scholar and a Sufi because he was busy with worldly things and had a lot of wealth. However, calmly he answered that he just wanted to need God, only God. And Even to make any impression showing he needed other things such as

\footnotetext{
37 Ibnu Hajar al Asqalani, Fathul Bari Syarah Shahih al Bukhari: Vol.3, Translated by Amirudin, (Jakarta: Pustaka Azzam, 2002), p. 82

38 Al Baqarah:180

39 Muhammad Quraish Shihab, Wawasan al- Qur'an, (Bandung: Mizan, 1996), p. 397

40 Anwar \& Assegaf, Imam Ali Abil Hasan As-Shadhili........, p. 91
} 
wearing bad clothes, he did not want ${ }^{41}$. In other words, he wanted to be rich because he just wanted to rely on Allah.

Umar May Allah be pleased with him was asked what the hardest burden is. And his answer is كثرةالعيال و قلة المال to have a lot of families but have a little wealth ${ }^{42}$. Wealth is the tool to do our obligation and goodness. Allah himself gave the prophet self-sufficiency. And He found you poor and made [you] self-sufficient. (QS Al-Dhuha: 8)

$$
\text { وَوَجَدَكَ عَائلاًَ فَأَغْنَى (الضَحى:م) }
$$

According to Quraish Shihab, if wealth is bad, Allah would not call it as mercy in this ayah. Further, Quraish classified 3 elements to reach self-sufficiency (Ghina alNafs or al-Qana'ah means contentment); the first is to have an eagerness to get something and be able to achieve it; turn away the desire of ownership consciously, and the last one gives what has been owned to others sincerely. So, If one is not able to achieve what he desires and enjoys his inability, he can not be said as having Ghina anNafs because he does not meet the first element ${ }^{43}$.

The prophet's life was very simple. However, he lived in difficult time and in struggle of Islam. He was sent to reinvite people to the oneness of God and create the peace. His priority is his mission sent to this world. Rasulullah also said:

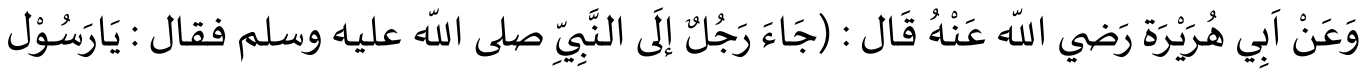

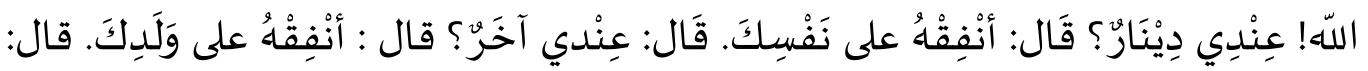

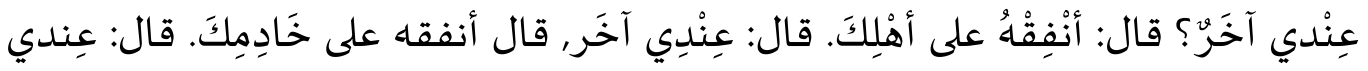

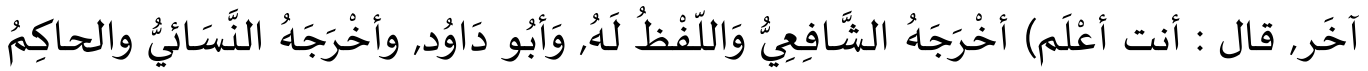

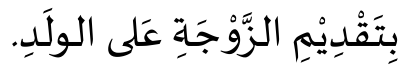

Abu Hurairah Radliyallaahu 'anhu (May Allah be pleased with him) said: there was a man coming to the prophet and said: "O the messenger, I have one Dinar? The prophet said: "use it for yourself". He said again: "I have another Dinar". The Prophet said: "use it for your children". He said again, "I have one Dinar again". The prophet said:" Give it to your wife". He said again: "I have one another Dinar". The prophet said: "Give it to your servant". He said: "I have one Dinar again". The prophet said:" You know better (to whom it needs to be given)". The narration of Syafi' $i$ and Abu Daud and the words are according to

\footnotetext{
41 Makmun Gharib, Syekh Abu Hasan al-Shadhili: Kisah Hidup Sang Wali dan Pesan-Pesan yang Menghidupkan Hati, Translated by Asy’ari Khatib, (Jakarta: Zaman, 2014), p. 66-67

42 Jamaluddin, Mau'idhatu al-Mu'inin, p.50

43 Shihab, Wawasan al- Qur'an, p. 397
} 
Abu Daud. Nasa'i and Hakim also narrated this hadith by mentioning the wife before the childrent ${ }^{44}$

This hadith reveals the priority of spending one's income. The head of the household is responsible for his/her family first before others. Giving a charity when his/her own child is starving is not a good virtue, even it is an exaggerated one. Allah says:

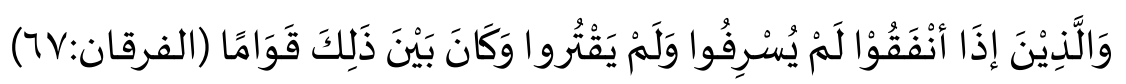

"And [they are] those who, when they spend, do so not excessively or sparingly but are ever, between that, [justly] moderate". (QS Al-Furqan: 67)

Shadhili used his wealth to maximize his devotion to God because the best struggle in His path is with one's wealth and soul ${ }^{45}$. From Abdillah bin Mas'ud, the Prophet said:

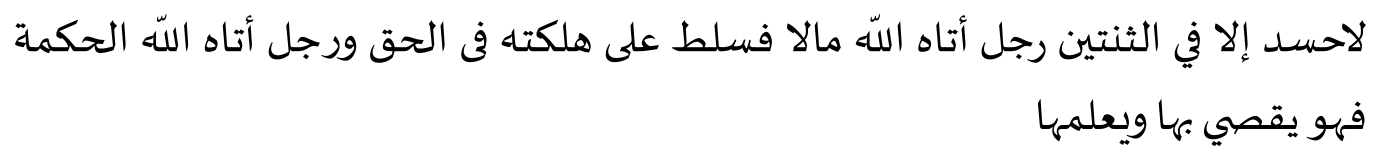

No envy except for two people, to the one who is given wealth by Allah and he uses it for good and to the one who is given knowledge by Allah and he practices and teaches it ${ }^{46}$.

Shadhili's role in society was very big. He helped and encourage the poor for a better life not only by his advice but also by his wealth ${ }^{47}$. He is both a scholar and a billionaire described, a man we need to be envy for a better world.

Through his prayers, the authors see Shadhili conquered the world and God conquered him. All he owned was used for His will and His creature. He lived a meaningful life by giving a huge positive impact on others.

$$
\text { سكن قلبي إلى غيرك فقد أشركت بك إلى منك القوت فقد طلبت غيرك. وإن سـألتك ما ضمنت لي فقد إههمتك. وإن }
$$

"O Allah, if I asked from You food giving me strength, I asked to another thing, not to You. And if I asked to You Your promise, I suspect You. And if my heart is peaceful with another thing save You, I betray You. ${ }^{48 "}$

\footnotetext{
44 Ibnu Hajar al-Asqolani, Bulughul Maram min Adillatil Ahkam, (Tasikmalaya: Pustaka Al-Hidayah, 2008) Hadith no. 1181

45 QS at-Taubah: 88-8.

46 Ibnu Hajar al Asqalani, Fathul Bari Syarah Shahih al Bukhari: Volume 3. Translated by Amirudin, ( Jakarta: Pustaka Azzam, 2002), p. 314

47 Anwar \& Assegaf, Imam Ali Abil Hasan As-Shadhili:........, p. 183

48 Ibid., p. 95-96
}

Teosofia: Indonesian Journal of Islamic Mysticism, Vol. 8, No. 1, 2019 


\section{J. Conclusion}

Sheikh Shadhili is just common human being and not ma'shum (free from sin) like the prophet Muhammad. Yet, he is a pious man in the presence of God and human beings. One thing that makes him very special as a Sufi is his concern with society, his sacrifice for people, and his country. At the age of 60, with blind eyes when France occupied Egypt (during the Crusade), he went to the battlefield and struggled for the Muslims. He argues that if all salik (man undergoing spiritual journey) who are honest and pious are busy with their religious ritual and leave their society, dishonest and greedy people will take power and only a few people care about worldly affairs of the Muslims. By learning from Shadhili's life, the authors conclude that tasawwuf is an inclusive way that can be pursued by every Muslim without ignoring their human nature to approach God. Therefore, tasawwuf is also called akhlaq tasawwuf (ethics and tasawwuf) because the more the believers learn and practice tasawwuf the more they will be ethical. Al-Kanani even says "tasawwuf is ethics, whosoever be ethical in his life he is a Sufi ${ }^{49}$."

49 Gharib, Syekh Abu Hasan....., p. 143 


\section{Bibliography}

\section{Books:}

Al-Asqalani, Ibnu Hajar, Fathul Bari Syarah Shahih al Bukhari vol. 3, terj. oleh Amirudin, Jakarta: Pustaka Azzam, 2002.

, Bulughul Maram min Adillatil Ahkam: Kitab Digital, Tasikmalaya: Pustaka Al-Hidayah, 2008.

Al-Qosim, Jamaluddin bin Muhammad, Mau'idhatu al-Mu'inin, Dar al-'Ulum alIslamiyyah.

Anwar, Miftahussurur, \& Mundhor, Ahmad Assegaf, Imam Ali Abil Hasan AsShadhili: Kepribadian dan Pemikirannya, Brebes: Al Anwar, 2002.

Anwar, Miftahussurur, \& Mundhor, Ahmad Assegaf, Sabilus Salikin: Jalan Para Salik Ensiklopedi Thariqah/Tasawwuf, Pasuruan: Pondok Pesantren Ngalah, 2012.

Gharib, Makmun, Syekh Abu Hasan al-Shadhili: Kisah Hidup Sang Wali dan PesanPesan yang Menghidupkan Hati, terj. oleh Asy'ari Khatib, Jakarta: Zaman, 2014.

HAG, Tamami, Psikologi Tasawwuf, Bandung: Pustaka Setia, 2011.

Ibrahim bin Ismail, Ta’lim al-Muta'allim, Kota Wali

Muhtarom, Pendidikan Tasawwuf, Semarang: Rasail Media Group, 2010.

Mulyati, Sri, Mengenal dan Memahami Tarekat-Tarekat Muktabarah di Indonesia, Jakarta: Kencana, 2005.

Nawawi, Hadari, Metode Penelitian Sosial, Jakarta: Rineka Cipta, 1997.

Rahman, Fazlur, Islam, Chicago \& London: University of Chicago Press, 1979.

Ridha, Rasyid, Tafsir al-Manar, Beirut: Dar al-Kotob al-Ilmiyah, 2005.

Salleh, Muhammad Syukri, Rethinking Wealth Management: An Islamic Preliminary View, International Journal of Business and Social Science, vol. 3, 2012.

Shihab, Muhammad Quraish, Wawasan al- Qur'an, Bandung: Mizan, 1996. , Al-Misbah Vol. 4, Jakarta: Lentera Hati. 
Sunan Ibnu Majah, 2012.

Syukur, M. Amin, Menggugat Tasawwuf: Sufie dan Tanggung Jawab Sosial Abad 21, Yogyakarta: Pustaka Pelajar, 1999.

, Tasawwuf Kontekstual, Yogyakarta: Pustaka Pelajar, 2000.

, Zuhud di Abad Modern, Yogyakarta: Pustaka Pelajar, 2004.

\section{Websites:}

http://islamicencyclopedia.org

http://islamicencyclopedia.org/public/index/topicDetail/id/88,

http://www.encyclo.co.uk/define/Julaybib 